\title{
The Construction of the Discourse Right of Ideology in Colleges and Universities in the New Media Era
}

\author{
Dong Yan \\ Academy of Marxism \\ Xi'an Science and Technology University \\ Xi'an China \\ 1392945250@qq.com
}

\begin{abstract}
Constructing discourse right of ideology can help to play the role of ideological and public opinion in colleges and universities in the new media era, and promote thigh moral values establishment and people cultivation. The construction of discourse right of ideology in colleges and universities are facing severe challenge in the new media era. It is necessary to proceed from the ideological and political education work in colleges and universities, to do a good job in class construction, and to optimize the ideological and political education from the aspects of discipline construction, teaching material innovation and teaching methods. It is of great significance to consolidate the construction of discourse right in Marx's ideology, and cultivate and carry forward the socialist core values.
\end{abstract}

Keywords-The new media era; Discourse right of ideology; ideological and political theory course in colleges and universities; construction

\section{INTRODUCTION}

The discourse right is the ideological leadership. The discourse subject dominant discourse orientation and resources to express their own ideas, values and political positions in order to influence the social development direction and the people's choice which is the basic way to obtain political leadership [1]. The construction of discourse right in colleges and universities is to consolidate the guiding position of Marxism in the ideological and political theory course, cultivate and carry forward the socialist core values so that Marxism and the core value of socialism with Chinese characteristics become the guiding for college students, Lay the scientific ideological foundation, guiding students to be the firm believers, active communicators, model practitioners for the socialist core values.

\section{THE CHALLENGE OF THE DISCOURSE RIGHT OF IDEOLOGY IN COLLEGES AND UNIVERSITIES IN THE NEW MEDIA ERA}

\section{A. The impact of multivariate coexistence discourse on college students' values}

In the new media era, the main battlefield of the network ideology struggle has been moved to colleges and universities. Western countries stepped up ideological expansion which impact on China's traditional discourse right of ideology, and ideological and political theory courses challenged by the various ideas of the network platform. At present, college students have become the largest consumer groups of online media. With the high degree of openness and freedom of choice of online media information, the western hostile forces regard colleges and universities as the first choice for cultural expansion and infiltration. They use the network platform to blur capitalism and socialism in the ideological distinction, in order to promote the Western political and economic system and the so-called "universal value", and regard the young students as erosion object. At the same time, the influx of Western bourgeois values, such as utilitarianism, money worship, individualism, hedonism, neoliberalism and other ideas have a great challenge and impact on the traditional value of college students, and seize the ideological territory of young people so that the cohesion and integration of Marxism have a serious reduction of some college students [2]. To a certain extent, it not only deconstruct the mainstream discourse right of ideology, but also challenge it [3].

\section{B. The danger of weakening discourse right of ideology in ideological and political theory course}

Western countries use the network technology to engage in ideological infiltration, peaceful evolution which is a no smoke war of network ideology, and cultivate the interests of the spokesperson in some domestic universities and research institutions. Some colleges and universities teachers obsessed with Western values, followed by the West's orientation, advocating colleges and universities should be "value neutral" non-political areas, calling for the abolition of the party system and ideological and political theory courses. With the immature ideas, world outlook and values have not formed of college students, some teachers attack on the national system in the classroom, and spread anti-socialist speech and "freedom, democracy, human rights" which is the theme of the Western political and social trends [4]. Several individual teachers received funding of foreign government or NGO organization to become "puppets" who implement political infiltration, political subversion, and "color revolution". The essential purpose of drumming up higher education to politicize, to the ideological is to promote historical nihilism and drum up socialism [5]. This demand us to comprehensively strengthen ideological and political theoretical team construction, and make a clear ideological discourse is the core of ideological and political theory courses. Teachers must regard the 
ideological and political theory course as the main front of propaganda and education of Marxist theory.

\section{THE IDEOLOGICAL AND POLITICAL THEORY COURSE IN COLLEGES AND UNIVERSITIES IS THE MAIN FRONT OF CONSTRUCTING THE DISCOURSE RIGHT OF IDEOLOGY}

\section{A. The importance of ideological work in colleges and universities}

As the main front of the propaganda of Marxist ideology, colleges and universities couldn't relax in the work of ideological discourse right, and must play the role of correct ideological guidance and educational norm. The CPC Central Committee has always attached great importance to the ideological propaganda and education. President Xi has made a series of important instructions, emphasizing the ideological work is an extremely important work, and the ruling party should firmly grasp the discourse rights of ideology. At the National Party Construction Work Conference held in December 2014, President Xi made important instructions on the Party building and ideological work in colleges and universities, emphasizing that colleges and universities shoulder heavy responsibilities of the research and propaganda of Marxism, and cultivate the builders and successors of the cause of socialism with Chinese characteristics. In December 2016 the National College ideological and political work conference President $\mathrm{Xi}$ stressed that the ideological and political theory courses in colleges and universities concentrate on the fundamental problem of what kind of people to train, how and for whom to do it. The ideological and political work in colleges and universities should be brought into the Party building work and ideological responsibility system to ensure that colleges and universities to become a strong position to uphold the Party leadership. Recently, the CPC Central Committee and the State Council issued the Opinions on Strengthening and Improving the Ideological and Political Work in Colleges and Universities under the New Situation (hereinafter referred to as the "Opinions") which pointed out that we should attach great importance to the ideological and political work of colleges and universities as the core of ideological work, using new media and new technology to make the ideological and political theory courses more effective, promoting a high degree of integration between the traditional advantage of ideological and political theory courses and information technology, play an educational function of philosophy and social science, enhancing attractiveness and the sense of times.

\section{B. The discourse right of ideology in colleges and universities should be emphasized in ideological and political theory course}

The ideological and political work in colleges and universities is an important part of the ideological work of the Party and the key point to cultivate qualified builders and successors of the cause of socialism. Therefore, the ideological and political theory course has a distinctive class and political nature, and there is an internal connection between ideological and political theory course and ideology [6]. In essence, the ideological and political theory course of colleges and universities is the education of ideology. Ideology not only runs through the ideological and political theory course of colleges and universities, but also the soul of it. The ideological and political theory course should grasp the discourse rights of ideology of Marxism, only in this way, it can give full play to the role of Marxism in the thought and guidance of college students, persisting in the nature and direction of running a socialist university, and cultivate qualified successors for the cause of socialism with Chinese characteristics. The socialism university with Chinese characteristics does not avoid the ideological attribute of the ideological and political theory course, opposing the westernization of the judging standard in academic research, and resolutely does not engage in the socalled "liberalism" and "neutrality". Colleges and universities are the main front of strengthening morality and cultivating talents for Party and state. It must not become a "radio station" that a minority people who loss Party spirit to reactionary advocate and spread erroneous ideological trend, and must not become an "Bridgehead" that overseas hostile forces make an ideological infiltration. Therefore, grasping the discourse rights of ideology in ideological and political theory course embodies the basic nature of socialist universities with Chinese characteristics, and determines what kind of talent to cultivate.

\section{THE BASIC PATH OF CONSTRUCTING IDEOLOGY DISCOURSE RIGHT IN COLLEGES AND UNIVERSITIES IN THE NEW MEDIA ERA}

\section{A. Strengthening the construction of discipline teams, grabbing the discourse expression in ideological education}

Construction of discipline team is the Key to discipline construction. Colleges and universities should take effective measures to strengthen the ideological and political theoretical disciplines team construction, and should have clear requirements and objectives in the construction of teaching and research organization, in selecting and training teachers and in providing discipline support, policy and system security. Colleges and universities should take the construction of subject and academic leader team into consideration, grasping the cultivation of discipline echelon and the backbone teachers, improving the incentive mechanism, encouraging the construction of ideological capacity of the first-line ideological and political education teachers, cultivating the ideological discrimination and theoretical innovation ability, improving the academic gold content of ideological and political education teachers, and standardize the expression of ideological education. Teachers can deepen the study of Marxist academic attainments and can accurately interpret the basic principles of Marxism and related classics, and have the ability to carry out dialogue with various non-mainstream ideologies, improving the identification of various erroneous ideas, resisting interference of Marxist ideology, and win the discourse rights in a thorough theoretical inquiry and interpretation. Only by striving to improve the academic content of ideological and political education can we make the ideological discourse right on the basis of Marxist academic discourse right which change the image of the ideological and political theory course is "propaganda" and political propaganda, It also can make ideological and political theory course with academic atmosphere and academic confidence. 
B. Strengthening the construction of teaching material system and innovate the discourse system of ideology in colleges and universities.

The innovation of ideology discourse system reflected in the construction of teaching staff. Colleges and universities should cultivate a group of theoretical talent who have political nature, fine business, a firm Marxist belief and understand China's national conditions and history to ensure the innovation of ideological discourse system. In the preparation of the contents of the teaching materials, we must handle the relationship between inheritance and innovation. We must adhere to Marxism as the guide, keeping the leadership position of Marxism and strengthening the road, theoretical and institutional confidence of socialism with Chinese characteristics. Based on the practice of China and contemporary interpretation of China's outstanding cultural traditions, it fully demonstrated the bright background of Chinese civilization, and extracted Chinese ideas with our own way of thinking and compiled textbooks of ideological and political theory with Chinese characteristics. Simultaneously, colleges and universities should draw on the achievements of foreign philosophy and social sciences, excavating the ideological resources have not yet reclaimed, seeking effectively dock of tradition and contemporary, theory and reality, and vigorously carry forward the wisdom of our traditional ideology discourse [7]. We can focus on compilation, promotion, usage, evaluation of teaching material, and actively explore the establishment of a more scientific and effective textbook quality assurance system.

\section{Changing the way of thinking and teach in various ways}

In the construction of the discourse rights of ideology, the ideological and political theory courses should innovate teaching content, but also have the fresh educational carrier and the form of expression. First of all, we must establish the "content-based" thinking, learning from the diversification and creativity of network discourse, enriching the ideological propaganda and education theme content through the "Internet ideology". Teaching quality should be improved to enhance the competitiveness of the classroom content. To strengthen the immediacy and improve the response speed, response quality and credibility hot spots, focus, sensitive problem [8]. The important educational purpose of the ideological and political theory course in colleges and universities is to make the college students with certain value judgment and theoretical thinking ability agree with the Marxist theory. With the participation of new media, the demands of equality, the ideological and political education should establish the equal communication mode of thinking. Teachers should lower their figure, treating others equally, using equal dialogue to exchange ideas, fully respecting the status and qualifications of the educated, using multimedia to build courseware, guiding students to understand the rationale of ideological and political theory from the individual or group discussion, playing the learning subjectivity of college students, and ensure the smooth implementation of educational activities and the effective realization of educational goals.

\section{CONCLUSION}

In order to construct the discourse right of ideology in colleges and universities in the new media era, we should strengthen the construction of the staff in ideological and political education. Colleges and universities managers should pay attention to discipline construction, to seize the ideological expression in ideological education; to enhance the construction of teaching materials, innovating ideological discourse system; changing the way of thinking, and take diversified forms of teaching. They should take abundant teaching carrier and manifestations so that college students believe in the guiding of ideological and political theory course, and consolidate the status and function of discourse rights of ideology in colleges and universities.

\section{REFERENCES}

[1] Zhuang Wencheng The Essence and Construction of the c Ideological Power [J] Journal of Graduate School of Chinese Academy of Social Sciences 2016.10.23

[2] Zhang Koulin, Yao Jie University Ideological and Political Theory Courses Must Grasp the Marxist Right of Discourse [J] Journal of Yangzhou University (Higher Education Research Edition) 2015.12

[3] Wang Jiepeng Construction of Mainstream Ideological Discourse of Colleges and Universities in the We-media Era [J] Journal of Huaihai Institute of Technology (Humanities and Social Sciences) 2016.7

[4] Wang Shufang A Contestant Perspective on the Competition of Network Ideological Discourse Right [J] Journal of Bohai University 2016.5

[5] Li Zhaoyu Grasping Ideological and Political Work in Colleges and Universities for Realistic Problems [J] Red flag manuscript 2017.1

[6] Ren Huifen The Ideological and Political Education of the Army in the New Media Era and the Prevention of "Ideology" [J] Research on Ideological and Political Education 2016.8

[7] Yang Renzhong, Lu Xiaoyong A Study on the Innovation of Ideology Discourse Construction Path in China [J] Journal of Henan Normal University (Philosophy and Social Sciences) 2016.11

[8] Kong Fanjun Deng Yonghua Establishes the Way of Thinking Adapts to the Network Ideological and Political Education [N] The Liberation Army Daily "Ideological Front" Edition 2017.2.24 